\title{
生体材料の表面処理
}

\author{
遠 藤 一 彦*, 大 野 弘 機*
}

\section{Surface Modification of Biomaterials}

Kazuhiko ENDO* and Hiroki OHNO*

Key Words : Biomaterial, Surface Modification, Biocompatibility

生体材料は，周囲組織と安定な界面を形成して機能しなければならない。生体材料の表面処理法に関 して, 特に細胞応答を考慮した生体適合性表面の創製に関する見状の取り組みと今後の動向について述 ベる。

\section{1.はじめに}

生体材料とは, 一定の期間人体の組織や器官の 解剖学的な形態を回復したり, 機能の一部むしく は全部を代替するするために使用される材料であ る。生体材料の中でも, 人工関節, 人工歯根, お よび人工血管など，上皮下の生体内に一部もしく は全体を埋入して用いる人工デバイスをインプラ ントと言う。整形外科領域では，股関節や膝関節 を人工関節で置換する治療が一般的に行われてお り, その数は世界中で年間 $30 \sim 40$ 万症例に達し ている ${ }^{1)}$ 。また，臨床で使用されている人工歯 根の数は, 北米で年間約 30 万本, 日本で約 7 万 本と推定されている ${ }^{2)}$ 。21世紀には，我が国は 高度な高齢化社会を迎える。したがって, 喪失し た人体機能を回復し, 生活の質を維持するために, 生体材料を用いた置換医療が増々重要となるであ ろう。

\section{生体内に埋入して用いられる材料には，代替す}

\footnotetext{
* 北海道医療大学 歯学部歯科理工学講座（テ061-0293 北海道 石狩郡当別町金沢 1757)

Health Sciences Univ. of Hokkaido, School of Dentistry, Dept. of Dental Materials Science (1757, Kanazawa, Tobetsu-cho, Ishikari-gun, Hokkaido 061-0293)
}

る組織・器官によって, 金属, セラミックス, 高 分子，およびそれらの複合材料が使用されている。 これらの材料は，生体内における高い耐久性や周 囲組織との良好な力学的適合性を有していなけれ ばならない。また，材料表面は生体組織と直接接 触するため, 高い生体親和性が要求される。そこ で，生体内で異物性生体反応を惹起することなく， 生体組織と安定な界面を構築して機能するように, 生体材料には様々な表面微細加工ならびに表面処 理が施されている。

本稿では, 生体材料の中でも, 生体内に直接埋 入して用いられる材料の表面処理法について概説 する。特に，細胞応答を考慮した生体適合性表面 の創製に関する現状での取り組みと今後の動向に ついて述べる。

\section{2.インプラントと周囲組織}

生体内に埋入して使用される材料は，必然的に 生体組織と界面を形成する。材料が接触する生体 組織には, 主に, 上皮や結合組織などの軟組織と 歯や骨などの硬組織および血液がある（表 1 ）。

インプラントの種類によって表面に求められる 機能は大きく異なる。例えば，人工関節や人工歯 $-6-$ 
が介在することなく，骨組織が密着して速やかに 再建されなければならない（硬組織適合性）。一 方, 人工血管では, 血栓の形成によって血管内が 閉塞しないょうに，表面に血球系の細胞が付着し ないことが要求される（抗血栓性）。生体内で使 用される材料の表面処理法を検討する上で最む重 要なことは, 界面を構成する組織の構造および性 状を良く理解し, 安定に機能する界面の構築に有 効な表面状態を設計することである。

\section{3．インプラントと生体組織界面の特殊性}

現在実用化されている代表的なインプラントと

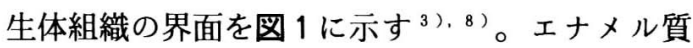
あ上皮の一部之考えると，菌冠修復物も上皮下に 埋入されるインプラントとして分類することがで

表 1 インプラントと周囲組織

\begin{tabular}{|c|c|}
\hline 生体組織 & インプラントの種類 \\
\hline 軟 組 織 & $\begin{array}{l}\text { 人工歯根粘膜貫通部, 人工乳房, 心蔵ペースメー } \\
\text { カー, 眼内レンス }\end{array}$ \\
\hline 硬 組 織 & $\begin{array}{l}\text { 人工苗根骨埋入部, 人工関節, 骨プレート, 苗冠 } \\
\text { 修復物 }\end{array}$ \\
\hline & 人工血管, 血液カテーテル \\
\hline
\end{tabular}

きる。各材料と生体組織界面の構造に関しては, 本小特集に掲載されている各々の解説を参照され た( 3)．8)。インプラントは, 生きた生体組織之 接触するため，その界面は常に動的である。例え ば，顎骨内に外科的処置によって埋入した人工歯 根の周囲組織は, 組織の修復過程で時間の経過と ともにダイナミックに変化する。骨組織が密着し て形成された後も，人工歯根周囲の骨組織は微小 血管網によって常に代謝しており，一定期間ごと にリモデリングされている ${ }^{9)}$ 。一般に，材料と 生体組織の接合は，金属とセラミックスなどの異 種材料間の接合とは本質的に異なり，生体組織の 恒常性を保ちながら，準安定的な界面を形成して 達成されている。人工材料が生体にとって異物で ある限り，完全に安定な界面は達成されないであ ろう。したがって，インプラントを介して伝達さ れる過度の応力やインプラントの劣化にともなう 化学的刺激, あるいは細菌感染などにより炎症が 生じると, 周用組織は破壊されていく10)。その 結果, 準安定的な界面は不安定な界面へ之移行し, 最終的にインプラントは生体外に排除される。現 在の人工材料を用いたインプラントでは，いかに 速やかに生体組織と準安定的な界面を構築するか

人工血管 / 血液界面 : 形成された偽内膜、侵入した内皮細胞

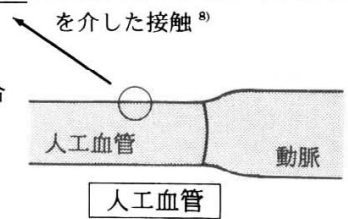

\section{金属製歯冠修復物}

金属 / セメント界面：接着性モノマーと金属の化学結合 凹凸による機械的維持

象牙質 /セメント界面 : 樹脂含浸層形成による接合 ${ }^{6)}$

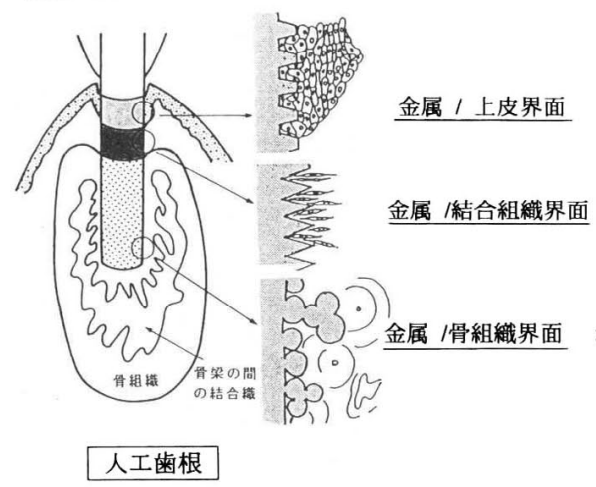

半接着斑形成による接着性 タンパク質を介した結命 ${ }^{3)}$

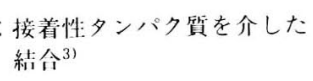
骨組織の侵入による機械的維持 4),7 微小血管網の形成と骨組織の リモテリング5

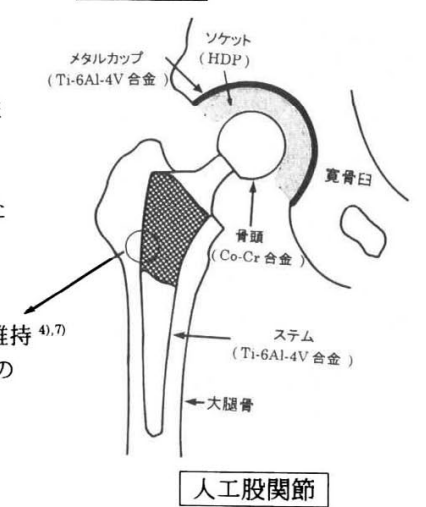

図 1 代表的なインプラントと周井組織の界面 
表 2 インプラントに対する表面処理の目的と方法

\begin{tabular}{|c|c|c|}
\hline 表面処理の目的 & $\begin{array}{c}\text { インプラント } \\
\text { の種類 }\end{array}$ & 表面処理の方法 \\
\hline $\begin{array}{l}\text { 接着性・接合強度の } \\
\text { 向上 }\end{array}$ & $\begin{array}{l}\text { 金属製歯冠 } \\
\text { 修復物 } \\
\text { 人工関節 } \\
\text { 人工歯根 }\end{array}$ & $\begin{array}{l}\text { ブラスト処理 } \\
\text { 多孔質金属コーティング } \\
\quad \text { (プラズマ溶射, 焼結) } \\
\text { 高温酸化処理 } \\
\text { Sn 電析 } \\
\text { Ga-Sn 液状合金塗布 } \\
\quad \text { (アドロイ処理) } \\
\text { 接着性プライマー処理 }\end{array}$ \\
\hline $\begin{array}{l}\text { 耐食性・耐摩耗性の } \\
\text { 向上 }\end{array}$ & $\begin{array}{l}\text { 人工関節 } \\
\text { 人工歯根 }\end{array}$ & $\begin{array}{l}\text { アノード酸化処理 } \\
\text { イオンプレーティング } \\
\text { イオン注人 }\end{array}$ \\
\hline $\begin{array}{l}\text { 生体機能性の付与 } \\
\text { （組織適合性の向上） }\end{array}$ & $\begin{array}{l}\text { 人工血管 } \\
\text { 人工関節 } \\
\text { 人工菌根 }\end{array}$ & $\begin{array}{l}\text { 化学修飾 } \\
\quad \text { (生体分子, 合成分子) } \\
\text { リン酸カルシウムコーティ } \\
\text { ング } \\
\text { (プラズマ溶射, イオンプ } \\
\text { レーティング, ダイナミッ } \\
\text { クミキシング法, Ca イオ } \\
\text { ン注入, アルカリ処理) }\end{array}$ \\
\hline
\end{tabular}

という問題と，構築された準安定的界面をいかに 長期間維持させ，かつ機能させるかという問題が 重要である。

歯質のエナメル質と象牙質の大部分は, 組織を 構築する細胞が存在しないため，例外的にリモデ リングされない組織である。したがって，接着技 術を応用した歯質と修復材料の接合法が適用可能 である6 ${ }^{6)}$

\section{4.表面処理の目的と方法}

インプラントの表面処理に関して，その目的と 方法をまとめて表 2 に示す。表面処理の目的は, （1）接合強度の向上,（2）劣化の抑制, (3) 生体機 能性の付与の三っに分類することができる。また, 目的を実現するために用いられている表面処理方 法は, 物理的方法, 化学的方法, および生化学的 方法など多岐にわたっている。以下に，各表面処 理法を目的別に分類して説明する。

\section{1 接合強度の向上}

材料と生体組織の接合強度を向上させることは, 特に硬組織代替材料にとって重要である。表面を 多孔質化して生体組織を in growth させること により，インプラントを機械的に維持する方法が 一般的である。純 $\mathrm{Ti}$ をプラズマ溶射した人工歯

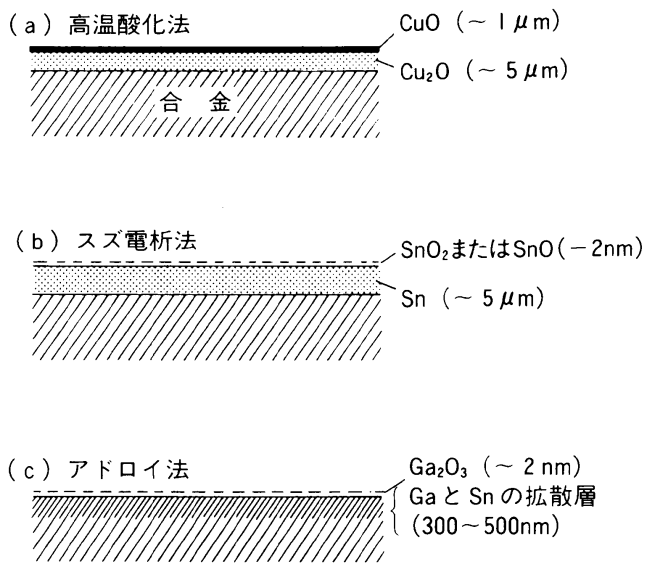

図 2 接着性を向上させるための貴金属表面改質法

根や繊維金属あるいは球状金属を焼結した人工股

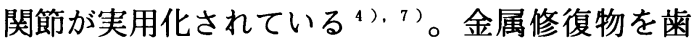
質に接着性レジンセメントを用いて接着する場合 には, 修復物とセメント間の接着強度を向上させ るために，金属被着面には様々な表面処理が施さ れている。特に, 貴金属合金は, セメント中に配 合されている接着性モノマーとの反応性が低いた め, (1) 高温酸化処理 ${ }^{11)}$, (2) $\mathrm{Sn}$ 電析 ${ }^{12}$, (3) Ga$\mathrm{Sn}$ 液状合金の塗布 ${ }^{13)}$ などを施し表面に杽金属成 分の酸化物皮膜を形成する（図 2 )。酸化物皮膜 の最表層に存在する水酸基と接着性モノマーの極 性基との間に水素結合，イオン結合あるいはキレー 卜結合が生じ, 接着されているものと考えられて (る ${ }^{14)}$ 。最近, 貴金属合金に化学吸着する接着性 プライマーも開発されている。接着性レジンセメ ントと象牙質の接合は，樹脂含浸層を形成するこ とにより達成されている。接着性レジンセメント 之金属ならびに象牙質との接着性の向上によって, 歯質削除量の軽減や包縁漏洩による二次う蝕の防 止などの効果が得られている。

\section{2 生体内における劣化の抑制}

腐食や摩耗によって, 生体内に埋入された材料 から生体組織中に放出される金属イオンや摩耗粉 は，一連の異物性生体反応を誘起する ${ }^{10)}$ 。その 結果, 炎症が持続して生じると, インプラントと 生体組織の界面は準安定的な状態加ら不安定な状 態となり，インプラントは最終的に生体外に排除 される。したがって，材料の劣化反応を抑制する 
表面処理は, インプラントと生体組織界面の安定 性を維持する上で, 極めて重要である。

現在，生体材料として臨床に用いられている Ti 合金（Ti-6Al-4V，Ti-50Ni）には，細胞毒性 を示す $\mathrm{V} や \mathrm{Ni}$ ，また，アルッハイマー型痴呆症 との因果関係が指摘されている $\mathrm{Al}$ が含まれてい る。耐食性を向上させて, 生体為害性を示す金属 イオンの溶出量を減少させる表面処理法が検討さ れている。Shirkhanzadeh は，硝酸ナトリウムを $1 \%$ 含有するメ夕ノール中にて，Ti-6Al-4V 合金 を電流密度 $5-20 \mathrm{~mA} \cdot \mathrm{cm}^{-2}$ でアノード酸化処理 し, 合金表面にはV を含まない厚い酸化物皮膜 が生成し，耐食性が向上することを報告してい $ろ^{15)}$ 。また，アークイオンプレーティング法を 用いて NiTi 形状記憶合金表面に TiN 皮膜を形成 すると, 生理食塩水中での腐食速度は $1 / 10$ 以下 に減小することが明らかとなっている ${ }^{16)} 。$

人工股関節では, 関節摺動部における骨頭とソ ケットの摩耗やステムの微動による摩耗によって, 金属粉や高密度ポリエチレンの削片が組織中に放 出される ${ }^{10)}$ 。人工股関節に広く利用されている $\mathrm{Ti}-6 \mathrm{Al}-4 \mathrm{~V}$ 合金は, ステンレス鋼や Co-Cr 合金と 比較すると耐摩耗性が低いので, Nイオン注入や $\mathrm{N}_{2}$ ガス中で加熱処理を施して表面を窒化するこ とにより, 摩耗量を低減化する試みがなされてい る ${ }^{17)}$ 。

\section{3 生体機能性の付与}

材料上における生体組織の構築や血栓形成の初 期段階で最も重要な生体反応は, 細胞による材料 表面の認識とそれに続き発現する細胞応答である。 生体組織の構築や血栓の形成は, 細胞によって行 われるからである。したがって，生体活性物質を 用いて材料表面を修飾し, 細胞の接着や増殖を制 御したり, 細胞の分化を誘導することは, 抗血栓 性表面や骨結合性表面の創製に有効と考えられる。 生体活性物質としては, タンパク質などの生体分 子や合成ペプチドなどが用いられている。無機化 合物では, 骨組織を伝導するリン酸カルシウムが 硬組織代替材料の表面コーティング材として広く 用いられている。

\section{3. 1 化学修飾法}

人工血管や血管カテーテルなどの血液接触面に
関しては，ポリウレタンやポリテトラフルオロエ チレンに凝血阻止剂であるへパリンや血小板粘着 阻止剤であるアルブミンを共有結合あるいはイオ ン結合させ，抗血栓性表面を実現している ${ }^{18)}$ 。 共有結合法でヘパリンを固定化する場合には， ス ペーサーの利用などにより，その活性が失われな いように工夫されている ${ }^{19)}$ 。硬組織代替材料と して用いられている金属に対しても生体機能性分 子を用いた化学修飾法が検討されている ${ }^{20), 21) 。 ~}$

図 3 に Ti 合金表面に接着性タンパク質として知 られるフィブロネクチン（pFN）を化学修飾した 表面上での㵶維牙細胞の形態を, 研磨面上での形 態と比較して示す ${ }^{20)}$ 。培養 30 分後から 120 分後 の間に, $\mathrm{pFN}$ 修飾面では細胞の接着・伸展過程 （球状 $\rightarrow$ 円形 $\rightarrow$ 紡錘形）が顕著に促進されてい る。この結果は，生体機能性分子を用いた金属表 面の化学修飾法は, 細胞応答を考慮した様々な生 体適合性表面の創製に有効であることを示唆して いる。図 4 に生体機能性分子で化学修飾した金属 表面の構造を示す。インプラントは, バルクの構 造体としての金属 (a), 不動態皮膜 (b)，架橋分子 (c) を介して結合される生体機能性分子 (d) から構 成される。このように, 金属表面の化学修飾によっ て，高い機械的強度および耐食性と生体活性を同 時に有する金属インプラントを開発することが可 能と考えられる。接着性タンパク質を用いた $\mathrm{Ti}$ 合金表面の処理は, 人工歯根の粘膜貫通部におけ る上皮および結合組織の構築に有効と考えられ $3^{3)}$ 。人工歯根の骨埋入部や人工股関節のステ ムには，骨形成タンパク質（BMP）を用いた処 理が検討されているが22), 今後の発展が期待さ れている。

4. 3. 2 リン酸カルシウムコーティング

人工関節や人工歯根に用いられている $\mathrm{Ti}$ 合金 は，骨組織との親和性を向上させる目的で，表面 にリン酸カルシウム（Ca-P) をコーティングす る場合がある。Ca-Pコーティングによって，(1) 表面上で骨組織が速やかに再建する，(2) 骨との 接合強度を高くする，(3) 繊維組織の介在なしに 骨之直接接触する, などの効果が実験的に確認さ れている ${ }^{23)}$ 。コーティングされた Ca-Pが骨組織 に対して良好な親和性を示す詳細な機構は不明で 

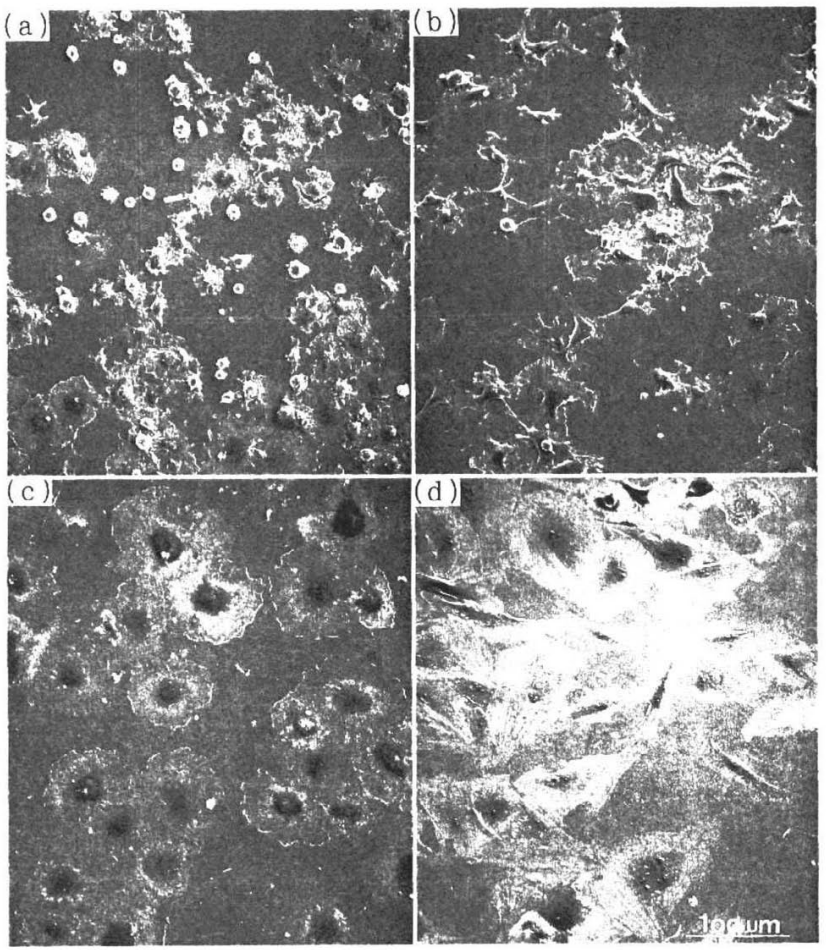

図 $3 \mathrm{Ti}$ 合金上の織維芽細胞の形態

(a) 研磨面，培養 30 分後

(b) 研磨面, 培養 120 分後

(c) $\mathrm{pFN}$ 修飾面, 培養 30 分後

(d) $\mathrm{pFN}$ 修飾面，培養 120 分後 培養液 : DMEM（無血清）

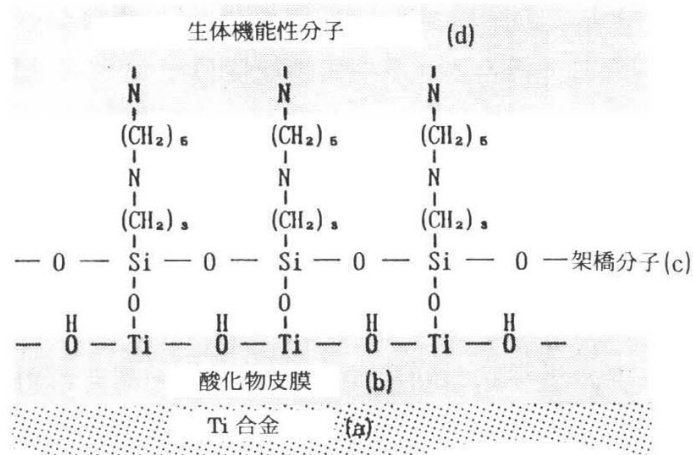

図4 生体機能性分子で化学修飾した $\mathrm{Ti}$ 合金表面の構造

あるが，局所に微量溶出する $\mathrm{Ca} イ$ オが骨の新 生を促進している可能性がある。

Ca-Pのコーティングは, 主にドライ・プロセ スで行われている。プラズマ溶射法によって CaPをコーティングした人工歯根が実用化され，臨

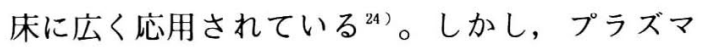
溶射によって形成された Ca-P層は 50〜 $100 \mu \mathrm{m}$ と 比較的厚いため, 長期間生体内で機能していると, コーティング層は破壊したり，あるいは金属から
はく離してしまうケースがある。そこで, イオン プレーティング法 ${ }^{25)}$ やダイナミックミキシング 法 ${ }^{26)}$ を適用し, 数 $\mu \mathrm{m}$ 以下の Ca-P 薄膜を形成す る表面処理法が検討されている。また，Caイオ ンを注入した Ti および $\mathrm{Ti}$ 合金を用い，生体内埋 入後速やかに Ca-Pを析出させ, 新生骨の形成を 促進することにあ成功している ${ }^{27)}$ 。

ウエット・プロセスに拈ける金属に対する $\mathrm{Ca}$ Pコーティング法としては, アルカリ処理法があ る ${ }^{28)}$ 。 $\mathrm{Ti}$ および $\mathrm{Ti}$ 合金を $10 \mathrm{M}$ の $\mathrm{NaOH}$ 溶液に 24 時間浸漬した後, 電気炉内にて $600^{\circ} \mathrm{C} て ゙ 24$ 時間 熱処理し，表面にチタン酸ナトリウムの薄膜を形 成する。このように処理された表面には，疑似体 液中で緻密で均一なアパタイトの皮膜が形成され る。ウエット・プロセスの長所を生かし，ポーラ スな Ti 合金表面への Ca-P コーティングが期待さ れる。

\section{5. 生体材料の表面処理に関する今後の展望}

インプラントを含めた生体材料の表面処理法の 中で, 今後発展すると考えられるのは, 生体組織 
の構築過程を模倣して材料の表面処理に積極的に 応用するバイオミメティックな表面改質法である。 例えば，生体内における石灰化過程では，コラー ゲンに共有結合したリンタンパク質側鎖のリン酸 基やカルボキシル基が，石灰化の核生成とその成 長に深く関与していることが知られている ${ }^{29)}$ 。そ こで，シランカップリング剂を用いて，これらの 官能基を $\mathrm{Ti}$ および $\mathrm{Ti}$ 合金表面に導入し，準安定 石灰化溶液に浸漬して Ca-P薄膜を形成する方法 が開発されている ${ }^{30)}$ 。人工血管の表面処理にも， バイオミメティックな表面改質法が検討されてい る。血管内壁を構成する内皮細胞の表面には糖夕 ンパク質分子が存在し，他の分子や細胞との非特 異的結合を阻止しているため，血管内壁には血液 タンパク質が吸着しない。このしくみを模倣し, オリゴ糖を用いた材料表面の化学修飾によって, 抗血栓性表面の創製を試みている ${ }^{31}$ 。

このように，生体の巧みな構造や機能を詳細に 解析し，生体材料の表面処理に積極的に適用する ことにより，本質的には異物である材料と生体の 共存が達成されるあのと考えられる。今後, 細胞 生物学や分子生物学を基礎として発展しているバ イオテクノロジーの手法と表面処理技術を含めた 材料創製の手法を融合させることにより，より生 体適合性の高いインプラントやバイオ人工臟器が 開発されていくことであろう。

(1998-6-8 受理)

\section{文献}

1 ) S. R. Goldring, A. L. Schiller, M. Roelke, C. M. Rourke, D. A. O'Neill, W. H. Harris ; J. Bone Joint Surg., 65-A, 575 (1983)

2) A. A. Campbell, G. E. Fryxell , J. C. Linehan, G. L. Graff ; J. Biomed. Mater. Res., 32, 111 (1996)

3 ）安彦善裕，賀来 亨; 表面技術，49，690（1998）

4 ）井上 孝, 吉成正雄, 鮎川保則, 田中輝男, 下野 正基 ; 表面技術，49，682（1998）

5 ）高橋和人, 岸 好彰, 松尾雅斗; 表面技術, 49, 696 (1998)
6 ）鈴木一臣，矢谷博文 ; 表面技術，49，702（1998）

7 ）大西啓靖; 表面技術，49，708（1998）

8 ）伊藤悦子, 岡野光夫 ; 表面技術，49，715（1998）

9 ）小澤英浩, 江尻貞一, 中村浩彰; 蛋白質核酸醭素, 40, 492 (1995)

10）遠藤一彦, 松田浩一, 安彦善裕, 大野弘機, 賀来 亨 ; 材料之環境, 46, 682 (1997)

11）田中卓男 ; 歯科理工学雑誌，21，95（1980）

12）山下 敦;補緅誌，28，1023（1984）

13) H. Ohno, Y. Araki, K. Endo ; J. Dent. Res., 71, 1326 (1992)

14）大野弘機 ; 歯界展望，85，1386（1995）

15) M. Shirkhanzadeh ; J. Mater. Sci. ; Mater. Med., 3, 322 (1992)

16) K. Endo, R. Sachdeva, Y. Araki, H. Ohno ;

Dent. Mater. J., 13, 228 (1994)

17）立石哲也，伊藤敦夫 ; 表面技術, 46, 893 (1995)

18) Y. Ikada; Biomaterials, 15, 725 (1994)

19）長岡昭二; 表面技術，46，916（1995）

20) K. Endo ; Dent. Mater. J., 14, 185 (1995)

21) K. Endo ; Dent. Mater. J., 14, 199 (1995)

22) T. Kawai, A. Mieki, Y. Ohno, M. Umemura, H. Kataoka, S. Kurita, M. Koike, T. Jinde, J. Hasegawa, M. R. Urist ; Clin. Orthop., 290, 296 (1993)

23) J. F. Kay ; Dent. Clin. North America, 36, 1 (1992)

24）田中 收, 近江谷尚紀, 舞田健夫, R. M. Meffert； ザ・クインテッセンス, 13, 161 (1994)

25) M. Yoshinari, K. Ozeki, T. Sumii ; Bull. Tokyo Dent. Coll., 32, 147 (1991)

26) M. Yoshinari, Y. Ohtsuka, T. Derand ; Biomaterials, 15, 529 (1994)

27) T. Hanawa, Y. Kamiura, S. Yamamoto, T. Kohgo, A. Amemiya, H. Ukai, K. Murakami, K. Asaoka ; J. Biomed. Mater. Res., 36, 131 (1997)

28) H. M. Kim, F. Miyaji, T. Kokubo, T. Nakamura ; J. Biomed. Mater. Res., 32, 409 (1996)

29) A. Linda ; Anat. Res., 224, 154 (1989)

30) A. A. Campbell, G. E. Fryxell, J. C. Linehan, G. L. Graff ; J. Biomed. Mater. Res., 32, 111 (1996)

31) N. B. Holland, Y. Qiu, M. Ruegsegger, R. E. Marchant ; Nature, 392, 799 (1998) 